\title{
RENAL AND URINARY FINDINGS IN 20 PATIENTS WITH WILLIAMS-BEUREN SYNDROME DIAGNOSED BY FLUORESCENCE IN SITU HYBRIDIZATION (FISH)
}

Sofia Mizuho Miura Sugayama, Vera Hermina Kalika Koch,Érica Arai Furusawa, Cláudio Leone and Chong Ae Kim

SUGAYAMA SMM et al. Renal and urinary findings in 20 patients with Williams-Beuren syndrome diagnosed by fluorescence in situ hybridization (FISH). Rev. Hosp. Clin. Fac. Med. S. Paulo 59(5):266-272, 2004.

PURPOSE: Williams-Beuren syndrome is a rare multiple anomalies/mental retardation syndrome caused by deletion of contiguous genes at chromosome region 7q11.23. The aim of this work was to determine the frequency and the types of renal and urinary tract anomalies in 20 patients with Williams-Beuren syndrome.

METHODS: The fluorescence in situ hybridization test using a LSI Williams syndrome region DNA probe was performed for all 20 patients to confirm the diagnosis of Williams-Beuren syndrome. A prospective study was performed in order to investigate renal and urinary aspects using laboratory assays to check renal function, ultrasonography of the kidneys and urinary tract, voiding cystourethrogram and urodynamics.

RESULTS: Deletion of the elastin gene (positive fluorescence in situ hybridization test) was found in 17 out of 20 patients. Renal alterations were diagnosed in 5 of 17 (29\%) the patients with the deletion and in 1 of 3 patients without the deletion. Fourteen patients with the deletion presented dysfunctional voiding. Arterial hypertension was diagnosed in 3 patients with deletions and 1 of these presented bilateral stenosis of the renal arteries.

CONCLUSIONS: Due to the high incidence of renal and urinary abnormalities in Williams-Beuren syndrome, performing a systematic laboratory and sonographic evaluation of the patients is recommended.

KEY WORDS: Williams-Beuren syndrome. Fluorescence in situ hybridization. Elastin. Renal abnormalities. Voiding dysfunction.

Williams-Beuren syndrome (WBS) is a rare genetic disease characterized by a typical dysmorphic faces, congenital heart defects, growth deficiency, teeth and skeletal anomalies, inguinal hernia, infantile hypercalcemia, mental retardation, distinct cognitive profile, overfriendly personality, and renal anomalies. ${ }^{1,2,3,4}$ Williams et al. in $1961^{1}$ and Beuren ${ }^{2}$ in 1962 independently described the syndrome. The estimated prevalence of WBS ranges between 1 in 7,500 to 1 in 25,000 newborns. ${ }^{5,6}$ The occurrence is usually sporadic in most families. ${ }^{5,6}$
Williams-Beuren syndrome is considered a segmental aneusomy syndrome that results from a hemizygous deletion of contiguous gene on the long arm of chromosome 7 (7q11.23). ${ }^{7,8}$ Most WBS individuals have a 1,5 megabase deletion in $7 q 11.23$ encompassing the elastin

From the Genetics Clinic Unit and Nephrology Unit of the Department of Pediatrics, Hospital das Clínicas, Faculty of Medicine, University of São Paulo - São Paulo/SP, Brazil.

Email: sofiamms@uol.com.br Received for publication on February 27, 2004. gene (ELN) and 25 gene to 35 genes. ${ }^{9,10}$ The phenotypic abnormalities of WBS are a result of the haploinsufficiency of the genes in this region. Hemizygosity of the ELN locus is responsible for cardiovascular abnormalities and connective-tissue abnormalities (dysmorphic facial features, prematurely wrinkled skin, hernia, joint laxity during infancy, hoarse voice, bladder and gut diverticula). ${ }^{11}$ LIM kinase 1 (LIMK1), a gene contiguous to ELN, and the second most frequently deleted gene in WBS patients, is expressed in the central nerv- 
ous system and it may be responsible for impaired visual motor integration. ${ }^{12}$

Diagnosis of WBS is by clinical evaluation, usually during infancy, when the typical facial and cognitive profile become more apparent. ${ }^{3,4}$ Approximately $99 \%$ of the patients of WBS have microdeletion in chromosome 7q11.23 encompassing ELN and is detectable by fluorescent in situ hybridization (FISH). ${ }^{13,14}$ This test is useful for confirming the diagnosis of WBS, because great clinical variability is present, hindering a diagnosis, especially in the first year of life.

Cardiovascular anomalies occur in $80 \%$ of the WBS patients. ${ }^{3,4,15}$ Aortic supravalvar stenosis is the most common cardiac defect, present in $64 \%{ }^{15}$ of the affected patients. Local and diffuse stenosis of the thoracic and abdominal aorta may also occur in WBS. ${ }^{16}$

The differential diagnosis for WBS includes Noonan syndrome ${ }^{17}$ and fetal alcohol syndrome, both of which can be associated with congenital heart disease and developmental delay.

Idiopathic hypercalcemia is documented in only $15 \%$ of affected patients and disappears by the end of the second year of life ${ }^{18}$. Abnormalities in the regulation of 25-hydroxyvitamin D have also been described in patients with WBS; however the cause of the hypercalcemia remains unknown. ${ }^{19}$

The estimated incidence of renal abnormalities in WBS is $18 \%{ }^{20,21}$. The congenital structural renal defects include ectopia, agenesis, hypoplasia, duplication, horseshoe kidney, asym- metry, hydronephrosis, vesicoureteral reflux and stenosis of the renal artery. ${ }^{20,21,22,23,24,25}$. Renal involvement can also be present as nephrocalcinosis, proteinuria and chronic renal insufficiency. ${ }^{20,21,24,26,27}$ Arterial hypertension is a frequent finding in $\mathrm{WBS}^{6,27}$, especially among adolescents and adults and can be secondary to stenosis of the renal arteries. ${ }^{4,20,22,24,28,30}$

A systematic investigation of the renal system and urinary tracts of 20 patients with WBS was undertaken in order to determine the frequency and the types of renal and urinary tract anomalies.

\section{METHODS}

The cohort of this prospective study consisted of 20 patients (11 males and 9 females) presenting with clinical features suggestive of WBS, followed-up at our institute, from 1999 to 2002. The mean age at the time of diagnosis was 5.9 years (range: 8 months to 10 years and 7 months). Conventional karyotyping using GTG banding in a peripheral blood sample was carried out in all patients.

The diagnosis of WBS was confirmed using the FISH test. This technique enables the determination of a specific deoxyribonucleic acid (DNA) sequence in a chromosome band. ${ }^{30}$ The technique involves the hybridization of a fluorescent- or radioactive-labeled probe to its complementary DNA segment within a metaphase chromosome. The probe is visualized with fluorescence in the FISH technique or with an

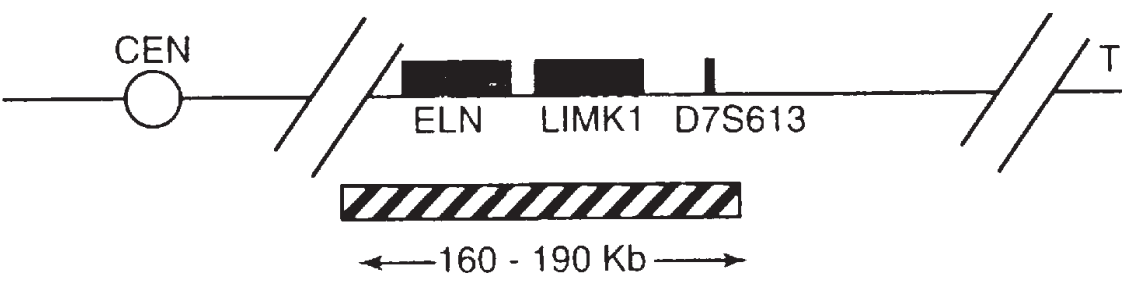

Figure 1 - Region 7q11.23 and VYSIS ${ }^{\circledR}$ LSI Williams syndrome probe.
$\mathrm{X}$-ray film. ${ }^{31}$ In our study, the hemizygosity for the elastin gene was analyzed using the LSI Williams syndrome region DNA probe $\left(\mathrm{VYSIS}^{\circledR}\right)$ (Figure 1), according to Pinkel et al. (1986). ${ }^{30}$ This is a specific-locus probe marked with Spectrum Orange ${ }^{\mathrm{TM}}$ dye, which contains the locus of the ELN, the locus of the LIMK1 gene, and the locus of D7S613, a marker of chromosome 7. The control probe marked with Spectrum Green ${ }^{\mathrm{TM}}$ is included in the mixture and corresponds to loci D7S486 and D7S522 located in the 7q31 band. Figure 2 represents the ideogram of chromosome 7 , showing the hybridization regions of the probe. The presence of only 1 red signal (elastin gene) and 2 fluorescent green signals (markers of chromosome 7) indicates deletion of elastin gene in one of the chromatids of chromosome 7, confirming the WBS diagnosis. In this case, the patient is considered FISH positive. The individual who has 2 red signals (presence of elastin gene in both chromatids of chromosome 7), and 2 green signals is considered FISH negative (Figures 3a, 3b).

The patient' $s$ medical histories were reviewed with emphasis on the occurrence of episodes of arterial hypertension, urinary lithiasis, urinary tract infection, or symptoms of dysfunctional voiding such as urinary incontinence or urgency. A complete physical examination was performed including weight: while barefoot and

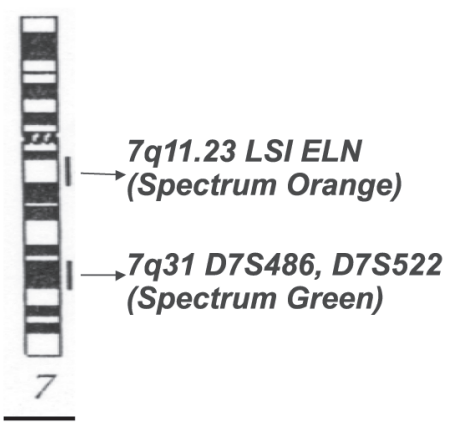

Figure 2 - Chromosome ideogram 7: regions of probe hybridization. 

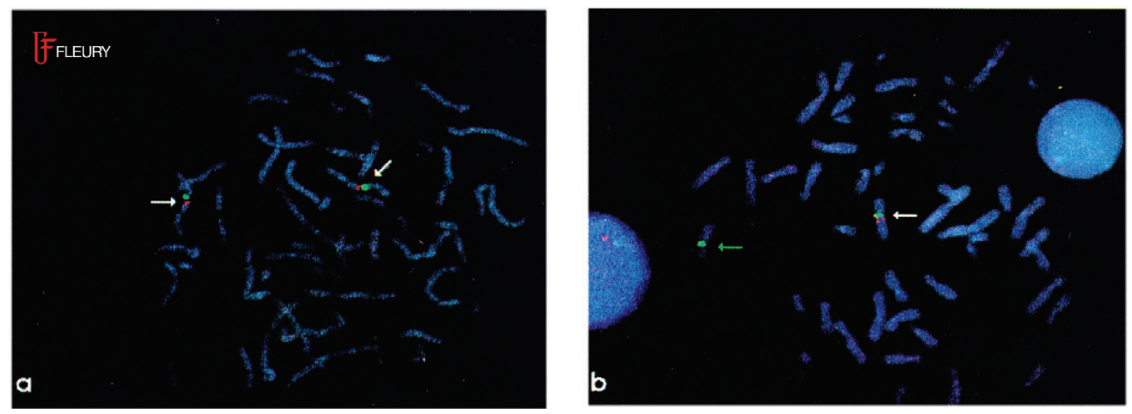

Figure 3 - a) Picture of FISH test for Williams-Beuren syndrome demonstrating metaphase with 2 red signals (elastin gene) and 2 green signals (markers of chromosome 7), therefore without elastin gene deletion (FISH-negative patient). b) Picture of FISH test for WilliamsBeuren syndrome demonstrating metaphase with 2 green signals (markers of chromosome 7) but only 1 red signal (elastin gene) showing the deletion of the elastin gene (FISH-positive patient).

using light clothing (Filizola scales, SP, Brazil - up to $150 \mathrm{~kg}$ ) and height measured with a wall anthropometer with the patient in upright position, barefoot, feet together, and keeping heels, buttocks, and shoulders in contact with the wall. Blood pressure was checked after 5 minutes of rest in the seated position by the auscultation method using a mercury column, with the right arm resting at heart level, positioning the stethoscope against the brachial artery, using an arm-sleeve cuff with an inflatable bulb with a length approximately covering $40 \%$ of the arm circumference measured mid-distance between the elbow and the acromion and sufficient length to completely involve the brachial perimeter. Systolic pressure was defined as the value of arterial pressure corresponding to Korotkoff phase I (KI), and diastolic pressure as the value corresponding to Korotkoff phase $\mathrm{V}$ of $(\mathrm{KV}) .^{32}$ Renal function was evaluated by laboratory determination of serum sodium, potassium, ionized calcium, bicarbonate, phosphorus, urea, and creatinine. Glomerular filtration rate was calculated utilizing the Schwartz formula. ${ }^{33}$ Urinary evaluation included urinalysis and a 24-hour urine collection for determination of sodium, potassium, uric acid, calcium, and citrate. Hypercalcemia was defined as total serum calcium $>10.5 \mathrm{mg} / \mathrm{dL}$ or ionized calcium > $1.32 \mathrm{mmol} / \mathrm{L}$. Hypercalciuria was defined as 24-hour urinary calcium excretion $\geq 4 \mathrm{mg} / \mathrm{kg} /$ day. Microscopic hematuria was defined as presence $>5$ red blood cells/ high power field in the urinary sediment. Renal and urinary tract investigation also comprised a renal ultrasound examination, which was completed by a Doppler study in hypertensive patients. A voiding cystourethrogram was performed for evaluation of urinary tract infection or dysfunctional voiding. Urodynamic evaluation was performed in patients with dysfunctional voiding. Clinically hypertensive patients were also evaluated by Tc $99 \mathrm{~m}$ DMSA scans in an attempt to diagnose renal scars and by magnetic resonance imaging of the aorta and renal arteries in order to rule out renal vascular malformations. Renal angiography for diagnosis of renovascular hypertension in selected cases with severe hypertension or abnormal magnetic resonance imaging of the aorta and renal arteries.

\section{RESULTS}

All patients presented with a typical face (Figure 4), delayed development/mental retardation, friendly personality, and dental and skeletal anomalies. All of our patients were considered sporadic since their parents were healthy. Conventional karyotyping yielded normal results in all 20 patients. Deletion of the elastin gene (FISH positive) was found in 17 out of 20 patients (the remaining 3 patients were FISH negative).

Laboratory tests (urinalysis, serum creatinine, creatinine clearance, and serum sodium and potassium) were normal in all patients. Renal abnormalities were diagnosed in 5 of $17(29 \%)$ of the FISH-positive patients and in 1 of 3 FISH-negative ones (Table 1). On ultrasound examination, renal echogenicity was normal in 2 FISHpositive patients $(15 / 17)$ and in 3 FISH-negative individuals (3/3). Small parapyelitic cysts were visible in 1 FISH-positive patient, and alteration of the renal texture was present in 2 FISH-positive patients. Microscopic hematuria was detected in 2 girls, one (FISH negative) of which presented associated intermittent hypercalciuria and the other (FISH positive) presented repeated urinary infections (RUI). Another patient (FISH positive) presented RUI and grade 3 vesicoureteral reflux (VUR) at the right kidney.

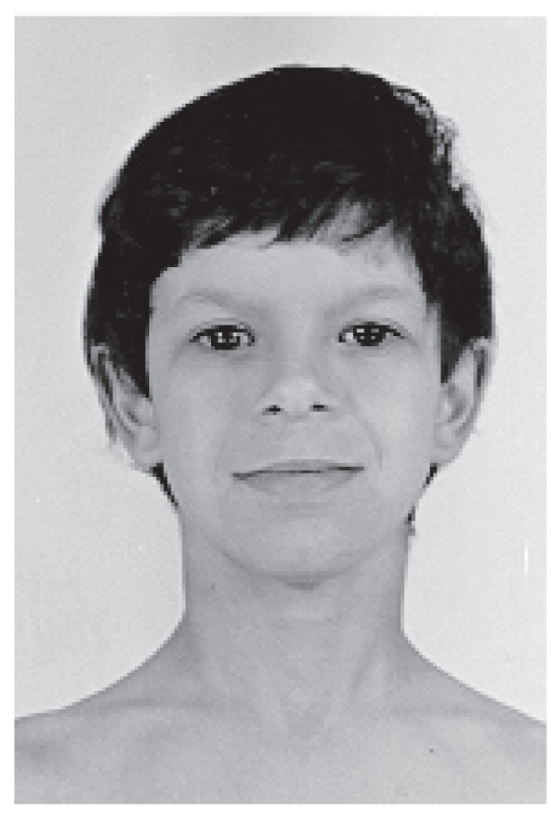

Figure 4 - 14-years-old patient with typical features of Williams-Beuren syndrome (FISHpositive). 
Fourteen FISH-positive patients were found to have dysfunctional voiding. Urodynamic evaluation was performed in 14 of 20 patients (13 FISH positive, 1 FISH negative), with normal findings in 4 patients (three FISH positive; one FISH negative), detrusor hyperactivity in 8 patients, reduction in bladder complacency in 3 patients, and high urinary pressure on micturition in 2 patients.

Arterial hypertension (AH) was diagnosed in 3 FISH-positive patients, in 2 of which, 16 years and 8 years of age, the AH was mild. Renal Doppler evaluation and magnetic resonance of the aorta and renal arteries was normal. Both were successfully treated with a salt-restricted diet.

One patient (FISH positive) at 14 years of age presented severe $\mathrm{AH}$ that was refractory to anti-hypertensive treatment due to bilateral stenosis of the renal arteries (Figure 1). Arteriography revealed $90 \%$ stenosis of the right renal artery, with ipsilateral retraction of the kidney and 50\% stenosis of the left renal artery. The abdominal aorta was narrowed but it was still pervious having flat and regular walls, and the celiac trunk and superior mesenteric artery were in the usual position without apparent lesions (Figure 5). The patient underwent angioplasty of the right renal artery, but without success; later, resection and reimplantation of the right renal artery was performed at the site of the stenosis.

\section{DISCUSSION}

The incidence of structural renal anomalies was found to be $18 \%$ in the classic studies of Pober et al. (1993) ${ }^{20}$ and Pankau et al. (1996) $)^{21}$, in which renal ultrasound was performed. The frequency of renal anomalies in the present study (30\%) was higher than that from those studies, probably due to the smaller sample size and systematic renal evaluation. Tables 2 and 3 present the renal anomalies among the patients with WBS in the present study and also in the main studies in the literature.

In the present study, $10 \%(2 / 20)$ of the patients presented abnormalities in the renal texture as revealed by ultrasonography. On kidney ultrasound examination of 25 children and adolescents with WBS, Coté et al. (1989) ${ }^{26}$ detected increased renal medullary

Table 1 - Renal abnormalities in 20 patients with Williams-Beuren syndrome.

\begin{tabular}{lcc}
\hline Renal abnormalities & $\begin{array}{c}\text { FISH positive patients } \\
(\mathrm{n}=17)\end{array}$ & $\begin{array}{c}\text { FISH negative patients } \\
(\mathrm{n}=3)\end{array}$ \\
\hline Small renal cysts & 1 & - \\
Alteration of the renal texture & 2 & - \\
Microscopic hematuria & 1 & - \\
Vesicoureteral reflux & 1 & 1 \\
Total & $5(29 \%)$ & $1(33 \%)$ \\
\hline
\end{tabular}

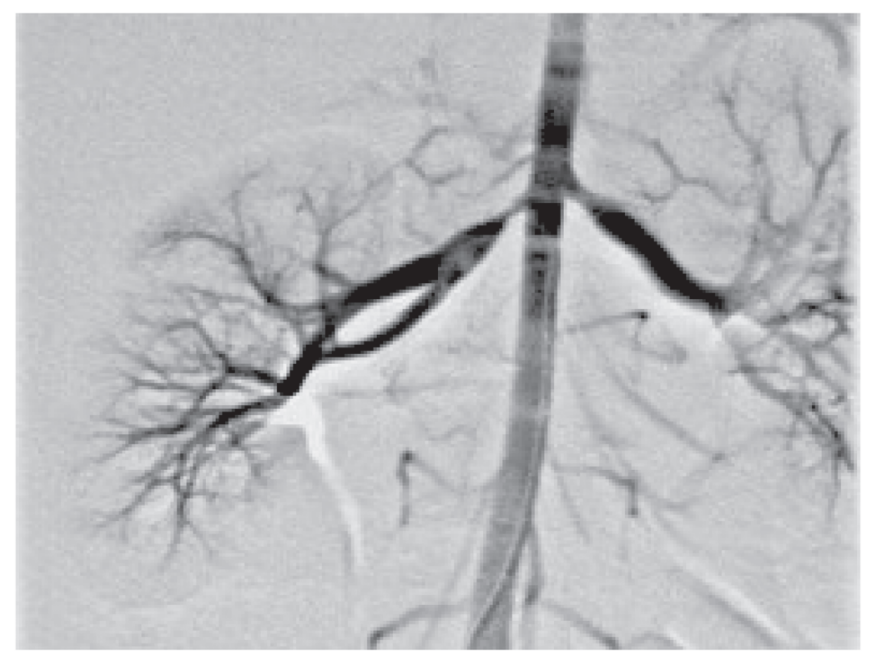

Figure 5 - Renal arteriography of Williams-Beuren syndrome patient (case 14).

Table 2 - Frequency of renal anomalies in patients with Williams-Beuren syndrome in the present study and in the literature.

\begin{tabular}{l}
\hline \\
Figure 5 - Renal arteriography of Williams-Beuren syndrome patient (case 14$)$. \\
\hline
\end{tabular}

echogenicity in $20 \%(5 / 25)$ of the patients. Infantile hypercalcemia was documented in 2 of 5 of these patients. Those children with normal levels of serum calcium, during the first year of life, did not develop nephrocalcinosis throughout the follow-up to 4 years. Both patients of our sample with abnormalities in renal texture presented intermittent hypercalciuria; however the serum calcium was normal. Increased renal medullary echogenicity is a nonspecific ultrasonography find- 
Table 3 - Types of renal abnormalities and their frequency among patients with Williams-Beuren syndrome.

\begin{tabular}{|c|c|c|c|c|c|c|c|}
\hline Author (year) & $\mathrm{n}$ & Renal agenesy & $\begin{array}{c}\text { Duplicated } \\
\text { kidney }\end{array}$ & $\begin{array}{c}\text { Dystopic } \\
\text { kidney }\end{array}$ & renal cyst & VUR & nephrocalcinosis \\
\hline Stoermer et al. $(1984)^{29}$ & 14 & - & 3 & 1 & 1 & 2 & 1 \\
\hline Ingelfinger, Newburger $(1991)^{27}$ & 32 & 2 & - & 1 & - & - & - \\
\hline Pober et al. $(1993)^{20}$ & 40 & 1 & - & 1 & - & 1 & 2 \\
\hline Pankau et al. $(1996)^{21}$ & 13 & 5 & 9 & 3 & - & 5 & - \\
\hline Sforzini et al. (2002) ${ }^{35}$ & 57 & 1 & 2 & 1 & 3 & - & - \\
\hline Present study (2003) & 20 & - & - & - & 1 & 1 & - \\
\hline
\end{tabular}

VUR $=$ vesicoureteral reflux

ing, that could be due to deposits of calcium, protein, or urates and also to medullary tubular ectasia. ${ }^{26}$ Patients with WBS can present persistently high serum calcium for months but usually return to normal levels during the second half of the first year of life. ${ }^{18}$

The occurrence of hypercalcemia was not documented in any of the 20 patients in the present work. The incidence of hypercalcemia documented in the literature is $15 \%^{18}$ in patients with WBS and, when present, frequently occurs within the first 18 months of life. The frequency of hypercalciuria in our sample was 32\% $(6 / 19)$ and thus was similar to the $30 \%$ reported in the literature ${ }^{18}$.

The frequency of VUR in the present study was $5 \%(1 / 20)$, which was similar to that reported in the literature, $3 \%$ in the work by Pober et al. $(1993)^{20}$ and $4 \%$ in the series of Pankau et al. (1996). ${ }^{21}$

In the present sample, the frequency of urinary complaints was $75 \%$ $(15 / 20)$. This percentage was greater than of Schulman et al. (1996) ${ }^{33}$ who studied 41 patients (18 males and 23 females; mean age, 9.4 years) affected by WBS. More than $30 \%$ of the patients studied by those authors presented high urinary frequency, incontinence, or urinary tract infections.

Urodynamic evaluation revealed abnormalities in 8 of $14(57 \%)$ patients of the present sample. This frequency was greater than that of the study by Schulmann et al. (1996), ${ }^{36}$ in which the frequency $32 \%$ (13/41). Detrusor hyperactivity was the most frequently observed abnormality (75\%) in the present study. Involuntary contractions of the detrusor muscle of the bladder were detected in $25 \%$ of our patients. This latter percentage was greater to that observed by Schulmann et al. $(1996)^{36}$, which was 10\% (4/41).

Table 4 shows the frequency of arterial hypertension $(\mathrm{AH})$ among the patients with WBS of the present study and in the main studies in the literature. The risk of developing $\mathrm{AH}$ increases with the patient' $s$ age.

The incidence of narrowing and stenosis of the renal artery in the literature is variable in WBS. Pober et al. $(1993)^{20}$ investigated the frequency of stenosis of the renal artery in 9 patients that underwent abdominal angiography during cardiac catheterization. The mean age at the time of catheterization was 6 years (range, 1-17 years). The authors observed slight unilateral or bilateral narrowing of the renal artery in 4 patients and normal renal arteries in the remaining 5. Persistent ar- terial hypertension occurred in only 2 patients, and there was no correlation with the state of the renal artery. Pankau et al. (1996) ${ }^{21}$ observed narrowing of the renal artery in (44.4\%) patients in the abdominal angiography performed during cardiac catheterization in 18 patients with WBS.

Some authors consider that the incidence of arterial stenosis and arterial hypertension are even higher, due to the finding of hypoplasia of the ascending aorta and of the aortic arch, and even more extensive stenoses of the aorta have been observed in a high number of patients. ${ }^{20}$ Furthermore, it should be noted that such narrowing or stenosis of the renal artery was not systematically investigated in many series of WBS patients and there are few data regarding abdominal angiography.

Due to the high incidence of renal and urinary abnormalities in WBS, ultrasound examination of the kidneys and urinary tract should be performed for both symptomatic and asymptomatic patients, and a urine test for the

Table 4 - Frequency of hypertension in patients with Williams-Beuren syndrome in the literature.

\begin{tabular}{lcl}
\hline Author (year) & $\mathrm{n}$ & Frequency of Hypertension \\
\hline Martin et al. $(1984)^{28}$ & 117 & age $>18$ years: $63 \%$ \\
Morris et al. $(1988)^{4}$ & & infants: $17 \%$; age $>16$ years: $47 \%$ \\
Ingelfinger, Newburger $(1991)^{27}$ & 32 & mean age 19 years : $59 \%$ \\
Pober et al. $(1993)^{20}$ & 40 & age: 10.5 and 17 years: $2 / 40(5 \%)$ \\
Wessel et al. $(1997)^{37}$ & 142 & mean age 6.5 years: $19 / 45(42 \%)$ \\
Broder et al. $(1999)^{38}$ & 31 & mean age 19.9 years: $40 \%$ \\
Present study $(2003)$ & 20 & age: 11,14 and 16 years: $15 \%$ \\
\hline
\end{tabular}


calcium- to-creatinine ratio should be performed at the time of the diagnosis. ${ }^{18}$ Laboratory examinations and urinalysis should be carried out at least every year during chidhood for evaluation of renal function. Serum calcium should be measured every year throughout life if the patient is normocalcemic. ${ }^{18}$ If there is persistent hypercalcemia and/or hypercalciuria or nephrocalcinosis, referral to a nephrologist for management is advisable.

\section{ACKNOWLEDGMENTS}

The authors are grateful to Dr. Lisa Suzuki, MD, assistant doctor of the Image Diagnosis Service of ICr-HCFMUSP for performing the doppler ultrasonography of the kidneys; Dr. Roberto Blasblag, MD, assistant doctor of the Magnetic Nuclear Resonance Sector of HC-FMUSP, Dr Flavio Trigo Rocha, PhD, MD, Head of Urodynamics Sector of HC-FMUSP, Dr Cristiano
Mendes Gomes, PhD, MD, Dr. Zein Mohammed Sammour, MD, doctors of Urodynamics Sector of HC-FMUSP for performing the urodynamic studies. We also are in debt to Dr Maria de Loudes L. F. Chauffaille, PhD, MD, Head of Cytogenetics Service of Fleury Laboratory and Kikue Terada Abe, $\mathrm{PhD}$, biologist of the Instituto de Biociências-USP, for performing the FISH tests without cost for our study.

\section{RESUMO}

SUGAYAMA SMM e col. Achados renais e urinários em 20 pacientes com síndrome de Williams-Beuren diagnosticados pelo teste de hibridização in situ por fluoresceína (FISH) Rev. Hosp. Clin. Fac. Med. S. Paulo 59(5):266-272, 2004.

OBJETIVO: A síndrome de Williams-Beuren é uma rara síndrome de deleção de genes contíguos que cursa com múltiplas anomalias congênitas, deficiência mental e anomalias renais e urinárias. O objetivo deste trabalho foi determinar a frequiência e os tipos de anomalias renais e urinárias em 20 pacientes com síndrome de WilliamsBeuren diagnosticados pelo teste de hibridização in situ por fluorescência.

MÉTODOS: Estudou-se prospectivamente os aspectos renais e urinários através de avaliação laboratorial da função renal, ultrassonografia de rins e vias urinárias, uretrocistografia miccional e estudo urodinâmico. $\mathrm{O}$ teste da hibridização in situ por fluorescência com a sonda LSI Williams Region foi feito nos 20 pacientes com síndrome de Williams-Beuren para a confirmação do diagnóstico.

RESULTADOS E DISCUSSÃO: A deleção do gene da elastina (teste de hibridização in situ por fluorescência positivo) foi detectado em 17/20 afetados $(85 \%)$. As alterações renais foram diagnosticadas em 5/17 (29\%) dos pa- cientes com a deleção e em 1/3 dos indivíduos sem a deleção. Catorze pacientes com a deleção apresentavam disfunções miccionais. A hipertensão arterial foi diagnosticada em três pacientes com a deleção e um deles apresentava estenose bilateral das artérias renais.

CONCLUSÕES: Devido à elevada incidência de anormalidades renais e do trato urinário na síndrome de Williams-Beuren, recomenda-se realizar uma avaliação laboratorial e de imagem sistematizada nos pacientes.

UNITERMOS: Síndrome de Williams-Beuren. Hibridização in situ por fluoresceína. Elastina. Anormalidades renais. Disfunção vesical.

\section{REFERENCES}

1. Williams JCP, Barratt-Boyes BG, Lowe JB. Supravalvular aortic stenosis. Circulation 1961; 24: 1311-8.

2. Beuren AJ. Supravalvular aortic stenosis: a complex syndrome with and without mental retardation. Birth Defects 1972; OAS VIII: $45-56$

3. Jones KL, Smith DW. The Williams elfin facies syndrome. J Pediatr $1975 ; 86: 718-23$.

4. Morris CA, Demsey AS, Leonard CO, Blackburn B. Natural history of Williams syndrome: Physical characteristics. J Pediatr 1988; 113: 318-26.

5. Greenberg F. Williams syndrome professional symposium. Am J Med Genet 1990; 6: 85-8.
6. Strommme P, Bjornstad PG, Ramstasd K. Prevalence estimation of Williams syndrome. J Child Neurol 2002; 17: 269-71.

7. Francke U. Williams syndrome: genes and mechanisms. Hum Mol Genet 1999; 8: 1947-54.

8. Bayés M, Magano LF, Rivera N, Flores R, Pérez Jurado LA. Mutational mechanisms of Williams-Beurens syndrome deletions. Am J Hum Genet 2003; 73: 131-51.

9. Peoples R, Franke Y, Wang Y, Pérez-Jurado LA, Paperna T, Cisco $\mathrm{M}$, et al. A physical map, Including a Bac/Pac clone contig, of the Williams- Beuren Syndrome deletion region at 7q11.23. Am J Hum Genet 2000; 66: 47-68. 
10. Merla G, Ucla C, Guipponi M, Reymond A. Identification of additional transcript in the Williams- Beuren Syndrome critical region. Hum Genet 2002; 110: 429-38.

11. Ewart AK, Morris CA, Atkinson D, Jin W, Sternes K, Spallone P, Stock AD, et al. Hemizygosity at the elastin locus in a developmental disorder, Williams syndrome. Nat Genet 1993;5:11-6.

12. Frangiskakis JM, Ewart AK, Morris CA, Mervis CB, Bertrand J, Robinson BF, et al. LIM-kinase 1 hemizygosity implicated in impaired visuospatial constructive cognition. Cell 1996; 86: 59-69.

13. Lowery MC, Morris CA, Ewart A, Brothman LJ, Zhu XL, Leonard $\mathrm{CO}$, et al. Strong correlation of elastin deletions, detected by FISH, with Williams syndrome:evaluation of 235 patients. Am J Hum Genet 1995; 57: 49-53.

14. Nickerson E, Greenberg F, Keating M T, McCaskill C, Shaffer L G. Deletions of the elastin gene at $7 \mathrm{q} 11.23$ occur in approximately $90 \%$ of patients with Williams syndrome. Am J Hum Genet 1995;56:1156-61.

15. Kececioglu D, Kotthoff S, Vogt J. Williams-Beurens syndrome: a 30-year follow-up of natural and postoperative course. Eur Heart J 1993;458-64.

16. Sumboonnanonda A, Robinson Bl, Gedroyc Mwm, Saxton, HM, Reidy JF, Haycock GB. Middle aortic syndrome: clinical and radiological findings. Arch Dis Child 1992;67: 501-5.

17. Bertola D R, Sugayama S M M, Albano L M J , KIM C A, Gonzalez $\mathrm{CH}$, Noonan syndrome: a clinical and genetic study of 31 patients. Rev Hosp Clin 1999;54:147-50.

18. Morris, CA. Williams syndrome. Management of genetic syndromes. In: Cassidy, SB, Allanson, JE. 1st ed. New York: John Wiley and Sons, 2001. p. 517-33.

19. Taylor AB, Stern PH, Bell NH. Abnormal regulation of circulating 25-hydroxyvitamin D in the Williams syndrome. New Engl J Med 1982;306:972-5.

20. Pober, BR, Lacro RV, Rice C, Mandell V, Teele RL. Renal findings in 40 individuals with Williams syndrome. Am J Med Genet 1993 46:271-4

21. Pankau R, Partsch CJ, Winter M, Gosch A, Wessel A. Incidence and spectrum of renal abnormalities in Williams-Beuren syndrome. Am J Med Genet 1996;63:301-4.

22. Daniels SR, Loggie JMH, Schwartz DC, Strife J1, Kaplan S. Systemic hypertension secondary to peripheral vascular anomalies in patients with Williams syndrome. J Pediatr 1984;106:249-51.

23. Biesecker LG, Laxova R, Friedman A. Renal insufficiency in Williams syndrome. Am J Med Genet 1987;28:131-5.

24. Ino T, Nishimoto K, Iwahara M, Akimoto, K, Tokita A, Kaneko $\mathrm{K}$, et al. - Progressive vascular lesions in Williams syndrome. J Pediatr 1985;107:826.
25. Suzuki Y, Shimazaki S, Kaneko K, Ino T, Yabuta K. Rena abnomalities associated with Williams syndrome. [Letter]. J Pediatr 1992;121:667.

26. Cote G, Jequier S, Kaplan P. Increased renal medullary echogenicity in patientes with Williams syndrome. Pediatr Radiol,1989;19: $481-3$

27. Ingelfinger Jr, Newburger JW. Spectrum of renal anomalies in patients with Williams syndrome. J Pediatr 1991;119: 771-3.

28. Martin NDT, Snodgrass GJAI, Cohen RD. Idiopathic infantile hypercalcemia - A continuing enigma. Arch Dis Child 1984;59:605-13

29. Stoermer J, Olbing H, Hentrich F, Even K, Galal O, Bachmann J Das syndrom der supravalvulären aortenstenose (WilliamsBeuren-Syndrom) in verbindung mit veränderungem der niere und ableitenden harnwege. Monatss Kinderh 1984;132:110-

30. Stumm M, Tönnies, H, Wieacker, PF. Molecular cytogeneic techniques for the diagnosis of chromosomal abnormalities in childhood disease. Eur J Pediatr, 1999;158: 531-6.

31. Pinkel D, Straume T, Gray JW. Cytogenetic analysis using quantitative, high sensitivity fluorescence hybridization. Proc Natl Sci USA, 1986;83: 2934-38.

32. UPDATE ON THE 1987 TASK FORCE REPORT ON HIGH BLOOD PRESSURE IN CHILDREN AND ADOLESCENTS A working group report from the National High Blood Pressure Education Program. Pediatrics 1996;98:649-58.

33. Schwartz GJ, Haycock GB, Edelmann CM Jr, Spitzer A. A simple estimate of glomerular filtration rate in children derived from body length and plasma creatinine. Pediatrics, 1976, 58:25963

34. Grimm T, Wesselhoeft $\mathrm{H}$. The genetic aspects of Williams-Beuren syndrome and the isolated form of the supravalvular aortic stenosis; investigation of 128 families. Z Kardiol 1980; 69: 168-72.

35. Sforzini C, Milani D, Fossali E, Brabato A, Grumieri G, Bianchetti $\mathrm{M}$, et al. Renal tract ultrasonography and calcium homeostasis in Williams-Beuren syndrome. Pediatr Nephrol 2002;17:899902 .

36. Schulman Sl, Zderic S, Kaplan P. Increased prevalence of urinary symptoms and voiding dysfunction in Williams syndrome. J Pediatr 1996;129:466-9

37. Wessel A, Motz R, Pankau R, Bursch JH. Arterial hypertension and blood pressure profile in patients with Williams-Beuren syndrome. Z Kardiol 1997;86:251-7.

38. Broder K, Reinhardt E, Ahern J, Lifton R, Tamborlane W, Pober B. Elevated ambulatory blood pressure in 20 subjects with Williams syndrome. Am J Med Genet 1999; 83:356-60. 